\title{
STRATEGI BERSAING SEKOLAH TINGGI ILMU EKONOMI IBBI DIKOTA MEDAN
}

Alexander Barus

,Sarjani Purnama Purba

\begin{abstract}
Abstrak
Globalisasi ekonomi dunia mengakibatkan perubahan tatalaku, institusi dan kerjasama perdagangan antar Negara. Globalisasi itu sendiri merupakan suatu revolusi dalam pasar karena pasar menjadi semakin terbuka, seolah tanpa ada batas geografi. Khususnya ketika kita berbicara adanya kesepakatan free trade pada Negara-negara asean (MEA).

Kondisi dimana adanya keterbukaan pasar di negera-negara asean mendorong Negara dan masyarkatnya (pelaku bisnis dsb) harus menyikapi dengan positif pola/tata bisnis kedepan. Suatu produk atau jasa nantinya tidak hanya lagi memiliki pesaing sesama pelaku bisnis local tetapi juga pebisnis dari Negara lain ynag melihat potensi bisnis di Negara Indonesia. Kunci agar dapat bersaing modal manusia. Dan berbicara modal manusia, pendidikan/pelatihan merupakan faktor yang dominan dalam membentuk kinerja itu sendiri.

Sekolah tinggi ilmu rkonomi IBBI mulai berdiri pada tahun 1998 dan hingga pada saat ini, 2015 telah melalui pasang dan surut dalam jumlah mahasiswa. Tantangan usaha dalam bidang pendidikan pada tahun-tahun ini sangat berat karena pesaing banyak (pesaing local maupun nasional) dan tuntutan dari konsumen dalam hal ini mahasiswa untuk mendapatkan suatu layanan pendidikan yang bermutu baik dari sisi akademik maupun non akademik.

Pada penelitian ini semua data yang didapat akan dianalisa dengan menggunakan swot analisis sehingga akan melahirkan kekuatan, kelemahan, peluang dan ancaman dan menghasilkan berbagai alternative strategi kedepan dalam menghadapi persaingan kedepan.
\end{abstract}

Keywords: sekolah tinggi ilmu ekonomi IBBI, manajemen strategi, strategi analisis SWOT 


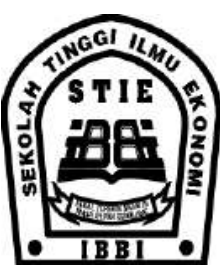

1. PENDAHULUAN

\subsection{Latar Belakang}

Memasuki pasar bebas muncul beberapa perubahan yang mendasar tata hubungan dagang diantara Negara-negara seperti, mudahnya perpindahan arus barang/jasa, factor produksi, tingginya lalulintas tenaga kerja dari satu Negara ke Negara lain lain. Kondisi ini membuat suatu Negara harus bekerja secara efisien dan efektif, agar perusahaan dapat bersaing sehingga produk atau jasa yang dihasilkan mempunyai daya saing baik pada tingkatan local, regional bahkan dipasar global.

Kondisi dimana adanya keterbukaan pasar di negera-negara asean mendorong Negara dan masyarkatnya (pelaku bisnis dsb) harus menyikapi dengan positif pola/tata bisnis kedepan. Suatu produk atau jasa nantinya tidak hanya lagi memiliki pesaing sesame pelaku bisnis local tetapi juga pebisnis dari Negara lain ynag melihat potensi bisnis di Negara Indonesia. Untuk memiliki daya saing tersebut, salah satu kuncinya ada kinerja perusahaan harus mampu bersaing dengan kinerja perusahaan pesaing lainnya baik dari dalam negeri ataupun dari Negara-negara luar. Kinerja perusahaan kalau ditarik lebih jauh kedalam perusahaan akan terlihat bahwa kinerja tersebut sangat dipengaruhi oleh modal manusia. Jadi modal manusia menjadi faktor pemicu terbentuknya kinerja perusahaan atau sebuah bangsa kedepan.

Industri pendidikan tinngi di kota Medan sangat bergeliat. Tahun ke tahun bermunculan lembaga-lembaga pendidikan, baik yang didirikan sebagai universitas, institute maupun sekolah tinggi. Ada Universitas Prima, Universitas Efarina, Universitas Sari Mutiara dan lain-lainnya yang ukurannya lebih kecil. Bahkan kampuskampus ruko juga menjamur menyediakan program studi berlomba untuk meraih mahasiswa sebanyak mungkin. Dan pada tahun-tahun belakangan ini, bermunculan perguruan tinggi-perguruan tinggi yang telah memiliki nama pada tingkat nasional seperti: Universitas Pelita Harapan, Wilmar Bisnis Institute. Kondisi ini mendorong setiap
ISSN 1858-3199

JURNAL

MANAJEMEN BISNIS

STIE IBBI

perguruan tinggi yang sudah di kota medan untuk lebih meningkatkan kualitas program studi dan aspek kualitas lainnya yang menjadi aspek yang diminati oleh para calon mahasiswa.

Sekolah tinggi IBBI merupakan salah satu sekolah tinggi diantara banyak sekolah tinggi atau institute atau universitas di kota Medan yang turut serta dalam membangun sumatera utara dalam bidang bisnis pendidikan. Tantangan usaha dalam bidang pendidikan pada tahun-tahun ini sangat berat karena pesaing banyak (pesaing local maupun nasional) dan tuntutan dari konsumen dalam hal ini mahasiswa untuk mendapatkan suatu layanan pendidikan yang bermutu baik dari sisi akademik maupun non akademik.

Pada penelitian ini, peneliti mencoba untuk mengkaji sekolah tinggi IBBi baik dari sisi internal maupun eksternalnya dalam rangka melahirkan langkah-langkah perbaikan kedepan.

\subsection{Perumusan Masalah}

1. Bagaimana lingkungan factor Internal sekolah tinggi IBBI mempengaruhi kinerja sekolah tinggi IBBI kedepan?

2. Bagaimana lingkungan eksternal sekolah tinggi IBBI mempengaruhi kinerja sekolah tinggi IBBI kedepan?

3. Bagaimana sekolah tinggi IBBI merumuskan strategi bersaing dalam rangka meningkatkan daya saing tinggi ditengah-tengah persaingan di bidang pendidikan yang semakin tinggi?

\subsection{Tujuan Penelitian}

Pelaksanaan penelitian ini diharapkan dapat memenuhi minimal 3 tujuan penelitian, yakni:

1. Mengkaji lingkungan internal sekolah tinggi IBBI secara menyeluruh meliputi kekuatankekuatan dan kelemahankelemahannya. 


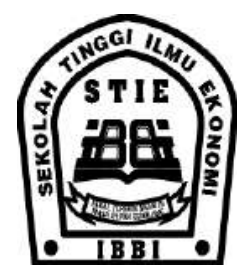

2. Mengkaji lingkungan eksternal sekolah tinggi IBBI berupa factor peluang yang dapat dimanfaatkan gapoktan serta Ancaman yang harus dihindari oleh perusahaan

3. Merumuskan alternative strategi bersaing bagi sekolah tinggi IBBI ke depan.

\subsection{Batasan Penelitian}

Ruang lingkup penelitian ini difokuskan untuk mengkaji kondisi internal dan eksternal sekolah tinggi IBBI serta merumuskan strategi sekolah tinggi IBBI kedepan.

\subsection{Luaran Penelitian} adalah:

Adapun luaran dari penelitian ini

1. Hasil penelitian ini dapat diterbitkan pada jurnal ber-ISSN tidak terakreditasi

2. Dapat memberikan kontribusi terhadap pihak-pihak yang berkepentingan atas hasil penelitian ini

\section{TINJAUAN LITERATUR}

\subsection{Landasan Teoritis}

\subsubsection{Manajemen Strategi}

Manajemen Strategi didefinisikan sebagai seni dan ilmu dalam merusmuskan, mengimplementasikan, dan evaluasi keputusan-keputusan lintas fungsional yang memampukan suatu organisasi mencapai tujuannya. (David, 2009)

Manajemen Strategi didefiniskan sebagai suatu kumpulan keptuusan dan tindakan yang member hasil dalam formulasi dan implementasi rencana yang didesain untuk mencapai tujuan perusahaan (pearce dan Robinson, 1997).

\subsubsection{Strategi Bisnis}

Menurut Minzberg dan Quinn (1996) strategi adalah pola dan rencana yang mengintegrasikan tujuan utama perusahaan, kebijakan-kebijakan dan urutan tindakan yang menyeluruh terpadu
ISSN 1858-3199

JURNAL

MANAJEMEN BISNIS

STIE IBBI

Jauch dan Glueck (1994), menyatakan strategi adalah rencana yang disatukan, menyeluruh dan terpadu yang mengaitkan keunggulan strategi perusaaan dengan tantangan lingkungan dan yang dirancang untuk memastikan bahwa tujuan utama perusahaan dapat dicapai melalui pelaksanaan yang tepat oleh perusahaan.

Strategi adalah sarana bersama dengan tujuan jangka panjang hendak dicapai (David, 2009)

\subsubsection{Proses Manajemen Strategis}

Menurut David (1999), proses manajemen strategi terdiri atas 3 tahap:

1. Formulasi Strategi

Formulasi strategi adaah proses merancang dan menyeleksi strategi agar misi dana tujuan perusahaan dapat tercapai.

2. Implementasi Strategi

Berdasarkan hasil formulasi strategi, diambil tindkaan untuk mencapai tujuan

3. Evaluasi Strategi

Pemantauan dan evaluasi terhadap aplikasi strategi yang telah dirumuskan, evaluasi tujuan ini bertujuan untuk memantau dan menganalisis apakah tujuan yang telah ditetapkan dapat tercapai melalui strategi yang dilaksanakan perusahaan

\subsection{Analisa Lingkungan Bisnis}

\subsubsection{Lingkungan Internal}

Keberhasilan suatu perusahaan sangat tergantung atas pengenalan diri perusahaan itu sendiri. Perusahaan harus dapat mengidentifikasi bagian-bagian kekuatan yang dimiliki, bagian kelemahan-kelemahan yang dimiliki.

\subsubsection{Lingkunga Eksternal}

Kehidupan suatu lembaga binsis atau non-bisnis dalam menjalankan perannya sangat dipengaruhi bukan saja dipengaruhi oleh kondisi internal perusahaan saja. Faktor-faktor diluar variable internal juga memiliki peranan yang sangat vital, terlebih-lebih ditengahtengah perubahan-perubahan yang sangat dinamis yang dodorong oleh perkembnagan ilmu pengetahuan dan teknologi. 


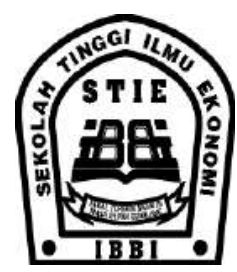

a. Lingkungan Makro

Lingkungan Makro terdiri dari komponen-komponen: ekonomi, social-budaya, politik, teknologi, hukum.

b. Lingkungan Mikro/Industri

Pemahaman karakteristik industry sangat vital dalam upaya merumuskan strategi bersaing, yakni cara perusahaan menyesuaikan diri serta merumuskan kesesuaian stratgei dengan lingkungan yang selalu berubah (Porter, 1997).

Lima kekuatan yang mempengaruhui persiangan dalam suatu industry:

\section{Penghalang masuk}

Beberapa factor yang berpengaruh terhadap penghalang masuk, yakni: skala ekonomi, diferensiasi produksi,persyaratan modal modal, akses distribusi, kebijakan pemerintah, keunggulan biaya.

\section{Penentu kekuatan pemasok}

Beberapa factor yang menentukan kekuatan pemasok, antara lain adalah: diferensiasi masukan, biaya peralihan pemasok dan perusahaan, adanya masukan pengganti, konsentrasi pemasok, pentingnya volumebagi pemasok, biaya yang berhubungan dengan pembelian total dalam dalam industry, dampak masukan pada biaya atau diferensiasi, ancaman integrasi kedepan yang berhubungan dengan ancaman integrasi kebelakang oleh perusahaan dalam industry.

3. Penentu ancaman produk pengganti

Beberapa factor yang mempengaruhi antara lain: kinerja harga relative dari pengganti, biaya peralihan,kecenderungan pembeli terhadap produk pengganti.

\section{Penentu persaingan}

Beberapa fakto yang mempengaruhi kekuatan persaingan antara lain adalah: perkembangan industry, biaya tetap (atau penyimpanan)/ nilai tambah, kelebihan kapasitas intermitten, diferensiasi produk, identitas merek, biaya peralihan, konsentrasi dan keseimbnagan, keragaman pesaing.

\section{Penentu kekuatan pembeli}

ISSN 1858-3199

JURNAL

MANAJEMEN BISNIS

STIE IBBI

Beberapa factor yang mempengaruhi: konsentrasi pembeli versus konsentrasi perusahaan, volume pembeli, biaya peralihan pembeli yang berhubung dengan biaya peralihan perusahaan, informasi pemebli, kemampuan untuk integrasi ke belakang, produk pengganti.

\section{METODE PENELITIAN}

\subsection{Metode Penelitian}

Dalam penelitian ini digunakan metode penelitian deskriptif kualitatif dalam bentuk studi kasus. Pemilihan metode ini bertujuan untuk memperoleh gambaran yang luas dan lengkap mengenai subjek yang diteliti.

\subsection{Lokasi Penelitian}

Penelitian ini dilaksanakan di sekolah tinggi IBBI

\subsection{Metode Pengumpulan Data}

Sumber Data pada penelitian ini berasal dari data sekunder dan primer. Dimana data sekunder diperoleh melalui dokumendokumen resmi yang tersedia di sekolah tinggi IBBI. Sedangkan data Primer di peroleh melalui wawancara yang mendalam dilakukan terhadap sejumlah pejabat-pejabat sekolah tinggi IBBI, dosen-dosen senior baik dari lingkungan sekolah tinggi IBBI maupun dari sekolah tinggi/perguruan tinggi diluar sekolah tinggi IBBI.

\subsection{Teknik Pengolahan dan Analisa Data 3.4.1 Analisis Matrik SWOT}

Analisis situasi perusahaan merupakan suatu cara untuk mendapatkan gambaran lingkungan strategis perusahaan dan kegiatannya yang ditinjau dari aspek internal dan eksternal yang dimiliki perusahaan. Analisis situasi perusahaan akan menghasilkan identifiikasi kemampuan khusus yang dimiliki perusahaan. 


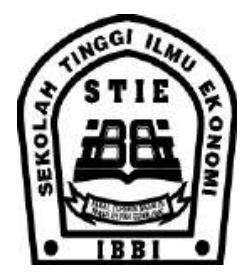

Table 3. Matriks SWOT

\begin{tabular}{|c|c|c|}
\hline \multirow{2}{*}{$\begin{array}{l}\begin{array}{l}\text { Faktor } \\
\text { Internal } \\
\text { Faktor } \\
\text { Eksternal }\end{array} \\
\end{array}$} & Kekuatan (S) & Kelemahan (W) \\
\hline & Strategi SO & Strategi WO \\
\hline $\begin{array}{l}\text { Peluang } \\
\text { (O) }\end{array}$ & $\begin{array}{l}\text { Susun strategi } \\
\text { dengan } \\
\text { menggunakan } \\
\text { kekuatan untuk } \\
\text { meraih peluang }\end{array}$ & $\begin{array}{l}\text { Susun strategi } \\
\text { untuk memperoleh } \\
\text { keuntungan dari } \\
\text { peluang yang ada } \\
\text { dalam mengatasi } \\
\text { kelemahan }\end{array}$ \\
\hline \multirow{2}{*}{$\begin{array}{l}\text { Ancaman } \\
\text { (T) }\end{array}$} & Strategi ST & Strategi WT \\
\hline & $\begin{array}{l}\text { Susun stratgei } \\
\text { dengan } \\
\text { memanfaatkan } \\
\text { kekuatan yang } \\
\text { ada untuk } \\
\text { menghindari } \\
\text { ancaman }\end{array}$ & $\begin{array}{l}\text { Susun strategi } \\
\text { dengan cara } \\
\text { meminimumkan } \\
\text { kelemahan dan } \\
\text { menghindari } \\
\text { ancaman }\end{array}$ \\
\hline
\end{tabular}

Sumber: Pearce dan Robinson, 1991

\section{HASIL DAN PEMBAHASAN 4.1. SEJARAH STIE IBBI}

IBBI dirintis pada tahun 1994 dan mulai dibangun pada tahun 1996. Didirikan, dibangun, didukung atas dasar harapan dari para pendiri dan pendukung untuk ikut serta yang semula dari kalangan bisnis elektronik sebagai mitra pemerintah menyelengarakan lembaga pendidikan tinggi di bidang ilmu ekonomi dan bisnis.

Dilakukan oleh beberapa tokoh formal maupun informal yang keseluruhannya terlibat dalam berbagai kegiatan baik secara berencana, pemikir dan pelaku ekonomi maupun bisnis di wilayah Sumatera Utara. Terdiri dari mereka yang berpendidikan program diploma khusus, S-1, S-2, S-3 bahkan guru besar serta beberapa orang praktisi. Untuk memenuhi harapan sebagai lembaga pendidikan tinggi yang layak serta representatif. Disediakan gedung permanen kemudian disebut sebagai kampus yang dipergunakan sebagai pelaksana proses belajar mengajar, dengan fasilitas yang sangat memadai.

Ketidakberdayaan pemerintah untuk meningkatkan angka Partisipasi Kasar secara lebih cepat disebabkan oleh keterbatasan dana dan prasarana yang tersedia apalagi mengingat kondisi ekonomi yang masih goncang-gancing seperti sekarang ini. Memang, tugas
ISSN 1858-3199

JURNAL

MANAJEMEN BISNIS

STIE IBBI

mencerdaskan kehidupan bangsa bukanlah semata-mata menjadi tanggung jawab pemerintah melainkan juga menjadi tanggung jawab seluruh masyarakat.

Menyadari akan hal tersebut Yayasan Pendidikan IBBI lahir ke tengah-tengah masyarakat dengan misi dan niat tulus untuk turut berpartisipasi memberikan pelayanan jasa pendidikan dalam upaya pencerdasan kehidupan bangsa sebagaimana yang diamanatkan oleh konstitusi. Dengan kehadiran lembaga ini berarti menambah daya tampung mahasiswa yang pada gilirannya berarti pula telah mengurangi beban pemerintah walaupun dalam kadar yang belum begitu signifikan. Dalam pada itu secara terus terang diakui bahwa lembaga ini tidak berpretensi mengklaim dirinya sebagai lembaga yang terbaik, namun mengingat komitmen para pendiri dan seluruh jajarannya untuk menjadikannya secara bertahap sebagai lembaga yang layak untuk diperhitungkan cukup tinggi, kiranya harapan tersebut bukanlah sesuatu yang bersifat utopis. IBBI ingin menjadikan dirinya sebagai mitra terpercaya pemerintah dan teman seiring perguruan-perguruan tinggi swasta lainya.

\section{Visi dan Misi}

Visi STIE IBBI adalah Menjadi sekolah tinggi yang unggul di wilayah Sumatera dalam menghasilkan sumber daya manusia bidang manajemen dan akuntansi pada tahun 2020 sedangkan Misi STIE IBBI adalah Menyelenggarakan proses pendidikan yang unggul sesuai dengan kebutuhan industri, Melaksanakan kegiatan penelitian dibidang manajemen dan akuntansi, Membangun kemitraan dengan lembaga yang terkait baik dalam maupun luar negeri dalam rangka pengembangan ilmu pengetahuan manajemen dan akuntansi, Melaksanakan kegiatan pengabdian masyarakat dalam rangka memberikan sumbangan terhadap pengembangan ekonomi usaha mikro, kecil dan menengah. Dari penetapan Visi dan Misi diatas jelas bahwa komitmen sekolah tinggi dalam mempersiapkan 


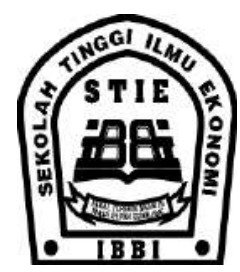

jalan menuju masa depan sekolah tinggi dengan lebih baik. Visi dan Misi tersebut diharapkan dapat mengawal sekolah tinggi sehingga dapat menghasilkan lulusan yang unggul berdaya saing dipasar tenaga kerja.

\subsection{Analisis Umum Keadaan Lingkungan Eksternal}

Sekolah Tinggi Ilmu Ekonomi IBBI memiliki visi untuk menjadi sekolah tinggi yang unggul di Wilayah Sumatera Utara dalam menghasilkan Sumber daya manusia unggul dalam bidang ekonomi dan manajemen. Apabila ditinjau dari sisi geografis, STIE IBBI merupakan sekolah tinggi yang berada di Provinsi Sumatera Utara yang terdiri atas 26 Kabupaten/ Kota. Sumatera Utara merupakan salah satu provinsi dengan jumlah penduduk yang padat. Sumatera Utara sebagai salah satu provinsi yang memiliki tingkat kemajuan dalam pembangunan yang cukup pesat diantara provinsi-provinsi lain di Indonesia memiliki kebutuhan yang sangat tinggi atas lulusan sarjana ekonomi. Lulusan sarjana ekonomi yang ada sangat dibutuhkan untuk mengisi tempat yang ada di berbagai bidang di perusahaan.

Tingginya kebutuhan akan lulusan pendidikan tinggi di Sumatera Utara saat ini difasilitasi oleh banyak perguruan tinggi. Perguruan tinggi yang ada di Sumatera Utara saat ini didukung oleh 2 perguruan tinggi negeri yaitu Universitas Sumatera Utara dan Universitas Negeri Medan. Selain itu, ada juga perguruan tinggi swasta yang saat ini berjumlah 237 perguruan tinggi. Keberadaan dari perguruan tinggi negeri dan swasta yang lain tersebut akan menjadi mitra dan sekaligus kompetitor bagi STIE IBBI dalam menjaga kelangsungan operasional dalam mencetak sumber daya manusia yang unggul di wilayah Sumatera Utara.

Sebagai suatu provinsi yang besar, sumatera utara memiliki jumlah sekolah menengah Atas yang juga terus bertambah banyak. Hal ini mengindikasikan kebutuhan terhadap perguruan tinggi oleh para lulusan SMA juga semakin tinggi di Sumatera Utara. Semakin tingginya kebutuhan akan perguruan
ISSN 1858-3199

JURNAL

MANAJEMEN BISNIS

STIE IBBI

tinggi inilah yang ingin dipenuhi oleh STIE IBBI untuk menjadi salah satu pilihan Sekolah Tinggi yang Terbaik diantara banyak Sekoilah Tinggi di Sumatera Utara, khususnya kota Medan.

Apabila dibandingkan rasio antara jumlah lulusan dari sekolah menengah atas, jumlah perguruan tinggi yang ada di sumatera utara cukup memadai, khususnya kota medan yang saat ini dihuni oleh dua perguruan tinggi negeri dan perguruan tinggi swasta. Namun, pada waktu belakangan ini, ada banyak perguruan tinggi yang harus menghentikan operasionalnya diakibatkan oleh banyak hal. Hal yang paling mendasar diakibatkan oleh kurang mampunya perguruan tinggi yang ada untuk memenuhi standar pendidikan tinggi yang ditetapkan oleh Direktorat Jenderal Pendidikan tinggi, Kementrian Pendidikan Republik Indonesia. Ketidakmampuan untuk memenuhi standar ini membuat perguruan tinggi sulit untuk bersaing.

Apabila ditinjau dari kemampuan bertahan berdasarkan masalah yang disampaikan sebelumnya, STIE IBBI merupakan suatu sekolah tinggi yang mampu bertahan ditengah tuntutan pemenuhan standar yang tinggi saat ini. Hal ini dapat dilihat dari kemampuan STIE IBBI untuk terus melanjutkan operasionalnya sejak pertama kali berdiri sampai pada saat ini. Kemampuan STIE IBBI untuk bertahan juga dapat dilihat dari konsistensi jumlah mahasiswa yang masuk mendaftar dan bahkan meningkat. Kemampuan STIE IBBI untuk terus bertahan pada dasarnya didukung oleh kekuatan STIE IBBI yang tidak dimiliki oleh perguruan tinggi yang lain, diantaranya lokasi STIE IBBI yang strategis yang terletak di pusat kota medan, Selain itu, daya tarik nama institusi STIE IBBI yang telah dikenal luas di masyarakat dan telah lama berdiri terutama di kota medan dan sumatera utara.

STIE IBBI telah berdiri pada tahun 1996, sejak tahun itu STIE IBBI telah menjadi perguruan tinggi pendukung yang menyediakan sumber daya manusia di bidang ekonomi, selain perguruan tingi negeri dan swasta yang lain yang telah berdiri sebelumnya. Sejak didirikan, STIE IBBI telah 


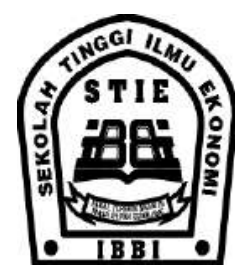

menghasilkan sebanyak ribuan lulusan dalam bidang ilmu ekonomi.

Dunia pekerjaan saat ini membutuhkan tenaga atau sumber daya manusia yang kreatif, inovatif dan mampu memiliki pemikiran yang kritis. Kemampuan tersebut dipercaya dapat menjadi pendukung bagi perusahaan dalam hal pengambilan kebijaksanaan strtegis perusahaan. Kebutuhan akan sumber daya manusia dalam bidang ekonomi seperti yang telah disebutkan sebelumnya harus dibentuk secara akademis pada saat perkuliahan dilaksanakan.

\subsubsection{Analisa Lingkungan Makro \\ 1. Faktor Ekonomi}

Faktor ekonomi pada dasarnya mempunyai pengaruh yang cukup kuat terhadap kemajuan suatu lembaga pendidikan. Faktor ini dampaknya cukup besar terhadap perubahan keinginan dari masyarakat khususnya terhadap layanan jasa pendidikan. Faktor ekonomi yang harus diperhitungkan antara lain: kemudahan untuk mendapatkan sumber dana dari luar, kemampuan masyarakat untuk membelajankan uangnya, tingkat suku bunga, tingkat pertumbuhan ekonomi, tingkat pendapatan masyarakat. Pada saat ini STIE IBBI dihadapkan pada kondisi perekonomian yang tidak menentu dimana tingkat pengangguran terus meningkat, daya beli masyarakat semakin merosot, pertumbuhan ekonomi yang masih rendah, dan berbagai kendala lainnya. Keadaan perekonomian yang kurang optimal tersebut dapat dianggap sebagai ancaman bagi peningkatan jumlah mahasiswa terutama bagi yang menanggung sendiri biaya perkuliahannya.

\section{Faktor Peraturan}

Faktor politik menyangkut hal-hal yang berkaitan dengan peraturan, kebijakan ataupun perudang-undangan yang diberlakukan oleh pemerintah. Salah satu peraturan yang sangat mempengaruhi STIE IBBI adalah ketentuan akreditasi dan kebijakan menyangkut pengembangan pendidikan tinggi yang diperlakukaan kementerian pendidikan.

\section{Faktor Teknologi}

ISSN 1858-3199

JURNAL

MANAJEMEN BISNIS

STIE IBBI

Adanya perkembangan dan perubahan teknologi baik dalam bidang teknologi pembelajaran maupun teknologi dalam bidang informatika mempunyai pengaruh yang sangat besar terhadap perkembangan ilmu manajemen dan akuntansi. Perubahan tersebut telah mendorong perubahan berkelanjutan di dalam dunia bisnis, Keadaan ini mentut STIE IBBI melakukan perbaikan berkelanjutan atas proses pembelajaran serta materi ajar yang diberikan bagi mahasiswa.

\section{Faktor Lingkungan}

Faktor ini mempunyai dampak pada penataan lingkungan kampus, karena umumnya kampus dituntut mempunyai lingkungan yang kondusif, nyaman, asri dan tenang serta memiliki kelengkapan sarana dan prasarana pembelajaran yang memadai. Hal ini mendorong yayasan untuk terus melengkapi sarana prasarana di lingkungan kampus untuk mewujudkan hal tersebut.

\section{Pesaing antar PTS, PTN dan PTA}

Pada saat ini terdapat banyak Perguruan Tinggi Swasta (PTS) disamping Perguruan Tinggi Negeri (PTN) yang sudah ada yang memperebutkan pasar yang relative sama. Keadaan ini mendorong setiap institusi untuk berbenah untuk menjadi semakin baik. Disamping hal tersebut, juga adanya kebijakan dari Dirjen Dikti yang memberi kesempatan kepada Perguruan Tinggi Asing (PTA) untuk membuka kelas khusus di Indonesia hal ini tentu akan menambah tingkat persaingan dalam merebut mahasiswa. Pada saat ini beberapa pesaing dari STIE IBBI di kota Medan dan sekitarnya adalah: STMIK - STIE Mikroskil,STIE ITMI, STIE Harapan, STIMM, STIE Graha Kirana Medan, STIE IBMI, STIE LM Imanuel Indonesia, STIE Nusa Bangsa, STIE Riama, STIE SWadaya, STIE Taman Harapan, STIE Tricom, STIE Pelita Bangsa dan lain-lain.

\subsubsection{Analisa Lingkungan Mikro}

1. Pelanggan. Jumlah potensi calon mahasiswa berdasarkan data BPS Sumut (2013) adalah sebesar 233,926 orang. Angka ini merupakan angka total jumlah siswa SMA/MA. Potensi ini cukup besar untuk diperebutkan oleh pelaku pengelola pendidikan. 


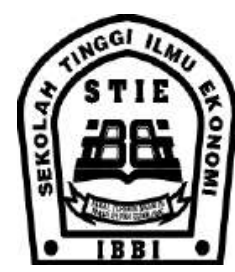

2. Pesaing. Jumlah perguruan tinggi di kabupaten/kota se Sumatera Utara berjumlah 253 (BPS Sumut, 2015) yang terdiri dari mulai Universitas, Institute, Sekolah Tinggi, Akademi dan politeknik.

\subsubsection{Analisa Lingkungan Industri}

1. Ancaman masuknya pendatang baru. Ancamannya masukknya pendatang baru di industri pendidikan sangat tinggi. Pada saat ini persaingan industri pendidikan dipasar medan dan sekitarnya tidak hanya dikelola oleh pengelola lokal. Tapi sudah mulai dilirik oleh pelaku pendidikan level nasional. 2 tahun belakangan ini saja ada beberapa perguruan tinggi baru yang masuk dalam melayani pasar Medan dan sekitarnya. Universitas Pelita Harapan dan Wilma Bisnis Intitute dan belakangan ini santer terdengar bahwa Podomoro Group juga merencanakan membuka perguruan tinggi "Podomoro University". Sedangkan pada level lokal, begitu banyak perguruan tinggi yang beroperasi.

2. Persaingan antar perusahaan yang ada dalam industri. Sejalan dengan banyaknya pendatang baru di industri ini, antar perguruan tinggi merasakan adanya tekanan kompetisi yang tinggi. Salah satu indikator menang bersaing adalah kemampuan perguruan tinggi tersebut merebut hati pada calon mahasiswa yang berencana untuk meneruskan pendidikan pada jenjang lebih tinggi lagi. Pada saat ini beberapa pesaing dari STIE IBBI di kota Medan dan sekitarnya adalah: STMIK - STIE Mikroskil,STIE ITMI, STIE Harapan, STIMM, STIE Graha Kirana Medan, STIE IBMI, STIE LM Imanuel Indonesia, STIE Nusa Bangsa, STIE Riama, STIE SWadaya, STIE Taman Harapan, STIE Tricom, STIE Pelita Bangsa dan lain-lain

3. Daya tawar menawar pelanggan. Dengan adanya kompetisi yang
ISSN 1858-3199

JURNAL

MANAJEMEN BISNIS

STIE IBBI

diakibatkan oleh semakin banyaknya perguruan tiggi yang beroperasi sangat memberikan keuntungan bagi calon mahasiswa. Karena calon mahasiswa memiliki banyak alternatif dalam memilih perguruan tinggi yang dianggap mememiliki banyak kelebihan dari perguruan tinggi lainnya.

4. Daya tawar menawar pemasok. Daya tawar pemasok pada industri ini belum begitu berkembang dengan baik. Karena pada dasarnya dalam memutuskan calon mahasiswa untuk lanjut studi di perguruan yang dipilih sepenuhnya tergantung dari calon mahasiswa dan atau oleh pihak keluarga. Bukan dari sekolah lanjutan atas tempat dimana siswa belajar.

5. Ancaman produk pengganti. Ancaman produk pengganti dari sekolah tinggi ini bisa saja berasal dari pembukaan kursus-kursus yang profesional yang menawarkan keterampilam khusus.

\subsection{Indentifikasi Faktor Internal dan Eksternal}

Berikut hasil indentifikasi faktor internal dan eksternal STIE IBBI

\section{A. Faktor Kekuatan}

1. Staf akademik dengan komitmen dan keahlian tinggi

2. Manajemen internal yang kuat dengan komitmen tinggi untuk pengembangan institusi. Adanya sinergis antara bagianbagian internal perusahaan dalam menjalankan peran dan tugas, sehingga tujuan dapat tercapai

3. Komitmen yayasan untuk terus mengembangkan institusi pendidikan tinggi yang memiliki standar yang baik.

4. Struktur organisai yang baik yang mendukung pencapaian visi dan misi. Struktur organisasi menggambarkan kekuatan internal dalam rangka mencapai visi dan misi.

5. Memiliki tenaga administratif yang cukup 


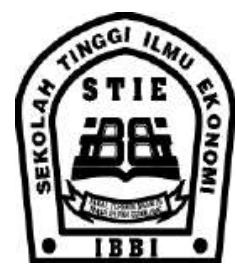

terlatih. Administrasi

yang menggambarkan kesehatan suatu organisasi. Organsiasi yang sehat otomatis mampu mengelola dan menghasilkan produk yang baik untuk dikonsumsi oleh masyarakat umum.

6. Memiliki jaringan kerja sama/kemitraan yang cukup luas khususnya kawasan Asia. Eksistensi suatu perguruan tinggi sangat dipengaruhi oleh seberapa luas jaringan kerjasama yang dijalin baik antara perguruan tinggi ataupun dunia usaha. Jaringan kerjsama trersebut apabila adapat dimanfaatkan dengan optimal akan menghasilkan suatu kekuatan sinergis dalam menghasilkan lulusan-lulusan yang terbaik.

7. Memiliki lingkungan kampus yang nyaman dan asri. Kanyaman merupakan suatu factor yang mempengaruhi secara langsung maupun tidak langsung eksistensi suatu perguruan tinggi. Hal ini berdampak terhadap minat masyarakat umum dalam menentukan kampus sebagai tempat menimba ilmu.

8. Minat meneliti dan mengabdi. Keinginan dan kemauan yang kuat dalam melakukan peneletian dan pengabdian pada dewasa ini memiliki peran yang strategis terhadap eksistensi suatu perguruan tinggi. Kecenderungan perguruan tinggi dewasa ini mulai dan sudah mengarahkan pengembangan menjadi kampus atau universitas yang berporientasi terhadap penelitian. Diharapkan dengan oreintasi ini, dunia usaha dapat memanfaatkan hasil-hasil penelitian dari dunia kampus untuk memajukan dunia usaha.

\section{B. Faktor Kelemahan}

1. Proses Belajar Mengajar masih berlangsung secara tradisional yang berpusat pada dosen. Motivasi yang tinggi mahasiswa dalam mengikuti perkuliahan

2. Keahlian yang dimiliki staf pengajar kurang merata untuk semua bidang keahlian. Dibutuhkan suatu pembangunan spesialisasi mata kuliah secara professional.
ISSN 1858-3199

JURNAL

MANAJEMEN BISNIS

STIE IBBI

3. Hanya memiliki program studi dan jenjang studi diploma dan sarjana. Pada saat masih hanya memiliki jenjang diploma dan sarjana.

4. Belum ideal rasio antara tenaga pengajar dengan mahasiswa. Rasio standard yang dipersyaratkan Dikti adalah 1 banding 40 mahasiswa. Kecukupan rasio berdampak terhadap kelancaran proses belajar mengajar disetiap kelas.

5. Kurangnya jumlah dan mutu bahan-bahan pustaka. Diperlukan penambahan koleksi buku/majalah/hasil penelitian atau pada saat ini sudah saatnya berbicara perpustakaan digital. Sumber-sumber pengetahuan ini sangat vital bagi perkembangan intelektual civita akademika.

6. Kurikulum pendidikan masih kurang dinamis. Belum adanya linkage antara dunia poendidikan dan industry secara nyata. Sehingga kebutuhan industry untuk sdm dengan kompetensi tertentu masih belum dapat terpenuhi dengan baik.

7. Penguasaan bahasa asing bagi Dosen dan Mahasiswa masih kurang. Bahasa asing sampai saat ini masih kendala besar bagi civitas akademika. Kendala bahasa berarti tertutupnya akses untuk mendapatkan pengetahuan terbaru dari luar.

8. Pemanfaatan teknologi informasi dan komunikasi belum optimal. Perlu peranan TI diperluas dan ditingkatkan penggunaannya. Sehingga dengan TI lalulintas data/informaso lancer sehingga proses pengambilan keputusan juga bisa dipersingkat.

9. Keterbatasan dana untuk pengembangan program studi. Dana merupakan masalah klise. Perlu adanya penggalangan dana dari sumber-sumber lain, seperti: alumi, pemerintah atau jaringan kerjsama dari luar negeri.

10.Belum optimalnya peranan alumni dalam mengembangan program studi. Alumni bisa bisa digerakkan sedemikian rupa, sehingga kontribusi alumni terhadap keberadaan kampus belum terlihat baik. 


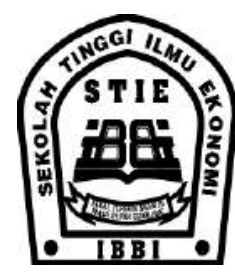

\section{Faktor Peluang}

1. Peluang kerja relative luas terutama untuk industri lokal Sumatera. Kebutuhan tenaga kerja yang baik masih memiliki peluang tinggi di kota medan dan sekitarnya. Lulusan dengan kualitas baik memiliki kesempatan besar untuk mendapatkan pekerjaan.

2. Tingginya minat masyarakat untuk mengikuti studi lanjut. Semakin disadari oleh masyarakat pendidikan pada dewasa ini berperan penting dalam meningkatkan kesejahteraan masyarakat secara meluas. Kenyataan ini akan mendorong terjaganya jumlah lulusan pendidikan lebih rendah untuk melanjutkan kependidikan lebih tinggi.

3. Potensi membangun hubungan industrial dengan berbagai perusahaan. Jumlah industry yang begitu besar perkembangannya di kota medan dan sekitarnya, mendorong terbentuknya kerjasama antara perguruan tinggi dengan industry yang sifatnya saling ketergantungan/membutuhkan.

4. Bantuan pendanaan eksternal baik berbentuk hibah maupun pendanaan yang berasal dari kerjasama. Terbukanya sumber pendanaan baik dari pemerintah Indonesia khususnya, merupakan suatu bantuan yang sangat besar dalam pembangunan dan peningkatan kualitas pendidikan di Indonesia.

5. Globalisasi dengan segala aspeknya memberi peluang Sekolah Tinggi untuk menjalin kerja sama dengan lembaga nasional maupun internasional dalam bidang pendidikan, penelitian dan pengabdian kepada masyarakat.

\section{Faktor Ancaman}

1. Perguruan tinggi negeri dan swasta yang memiliki program studi sejenis senantiasa melakukan peningkatan kualitas sehingga persaingan semakin ketat.

2. Kesinambungan kemitraan dengan indutri dapat mengalami hambatan jika tidak terdapat peningkatan kualitas secara nyata.

3. Peningkatan peraturan yang harus ditaati
ISSN 1858-3199

JURNAL

MANAJEMEN BISNIS

STIE IBBI

oleh semua institusi pendidikan tinggi agar tetap memperoleh izin operasional

4. Munculnya kebijakan deregulasi pendidikan yang memungkinkan beroperasinya Perguruan Tinggi Asing (PTA) di Indonesia. Terbukanya sector pendidikan luar negeri untuk ikut melayani masyarakay Indonesia khususnya pada bidang pendidikan, merupakan suatu ancaman serius terhadap keberadaan perguruan tinggi di kota medan dan sektiarnya khususnya.

5. Meningkatnya tuntutan sertifikasi untuk semua profesi di bidang pendidikan. Kualfikasi pendidik yang ditetapkan oleh pemerintah dari waktu ke waktu semkain tinggi. Hal ini apabila tidak disikapi dengan baik oleh tenaga pendidik, merupakan suatu ancaman serius bagi kariri kedepannya.

\subsection{Matriks IFE dan EFE}

Melalui Matriks IFE dan EFE posisi suatu organisasi ditampilkan dalam suatu diagram yang skematis. Dimana sumbu $X$ menggambarkan posisi IFE dan sumbu Y menggambarkan EFE, dimana wilayah yang dibatasi oleh kedua sumbu tersebut berisikan Sembilan sel. Berikut ini gambaran dari Matriks IFE dan EFE.

\subsubsection{Matriks IFE}

Dari table dibawah ini dapat dilihat bahwa posisi internal perusahaan menunjukkan nilai 2,509. Angka ini dimaknai dimana STIE IBBI berdasarkan matrik IFE dan EFE memiliki kemampuan berada diatas rata-rata industry. Dengan kata lain STIE IBBI kemampuan bersaing diatas rata-rata industry pendidikan di kota Medan.

\section{A. Kekuatan}

Dari matriks evaluasi Internal dan Eksternal hampir keseluruhan komponenkomponen kekuatan berada diatas rata-rata industry dimana rata-rata nilai per komponen kekuatan beada diatas angka 3. Dengan demikian apabila STIE IBBI mampu mengelola kekuatan tersebut sedemikian rupa 


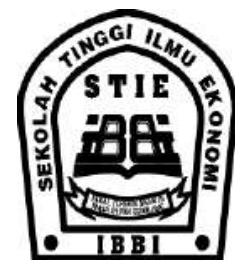

dapat menciptakan daya saing tinggi dibidang pendidikan di kota Medan.

\section{B. Kelemahan}

Dari matriks evaluasi Internal dan Eksternal hampir keseluruhan komponen-komponen kelemahan berada diatas rata-rata industry dimana rata-rata nilai per komponen kekuatan berada pada kisaran 2,88 sampai 3,50. Angka pada kisaran tersebut menggambarkan posisi STIE IBBI relative cukup lemah bila dibandingkan dengan para pesaing yang ada dipasar industry pendidikan di kota Medan. Posisi cukup lemah tersebut menjadi suatu acuan bagi pengelolaa STIE IBBI untuk melakukan perbaikan-perbaikan yang nyata dalam rangka meningkatkan daya saing STIE IBBI ditengah-tengah persaingan yang begitu ketat di industry ini.

\section{Peluang}

Dari matriks evaluasi Internal dan Eksternal hampir keseluruhan komponen-komponen Peluang diatas atau sama dengan 2,5 (2,50 = rata-rata industry). Posisi ini menempatkan STIE IBBI sebagai sebuah kampus yang memiliki kemampuan untuk memanfaatkan peluang-peluang yang muncul dari lingkungan luar STIE IBBI. Persoalannya adalah sangat tergantung dari bagaimana STIE IBBI dapat memanfatkan peluang-peluang untuk dimanfaatkan untuk peningkatan kinerja dan citra STIE IBBI di industry pendidikan di kota Medan dan Sekitarnya.

\section{Ancaman}

Dari matriks evaluasi Internal dan Eksternal hampir keseluruhan komponen-komponen Ancaman berada pada kisaran 2,12 5sampai dengan 2,65. Angka-angka pada komponen Ancaman menggamarkan kondisi institusi dalam menanggapi ancaman dari factor luar relatif cukup baik. Tapi pada kondisi persaingan yang begitu pesat di Industri ini, seharunya institusi berada pada posisi minimal baik dalam rangka menanggapi ancaman dari factor luar institusi. Pada komponen Ancaman, semakin tinggi nilai per kompnen penyusunan menggambarkan derajat ketidakmampuan institusi dalam merespon ancaman-ancaman dari factor luar institusi.
ISSN 1858-3199

JURNAL

MANAJEMEN BISNIS

STIE IBBI

\section{KESIMPULAN DAN SARAN}

\section{a. Kesimpulan}

1. Kesinambungan sebuah perguruan tinggi dipengaruhi oleh faktor internal perusahaan. Kesiapan internal dalam memanfaatkan peluang dan menghindari ancaman faktor luar merupakan kemutlakan untuk dapat bertahan dan berkembang ditengahtengah kompetisi tinggi.

2. Pemantauan perubahan-perubahan factor luar, seperti peraturan-peraturan terbaru didunia pendidikan, perkembangan teknologi, kuantitas dan kualitas persaingan dan selain sebagainya senantiasa diikuti sehingga dengan kekuatan internal dapat dioptimalkan dalam rangka meraih daya saing.

3. Dengan bantuan analisa matrik lingkungan internal dan eksternal perusahaan berada pada posisi " Hold and maintain " dan posisi ini mengarahkan perusahaan untuk mempertimbangkan beberapa strategi yang dihasilkan dari SWOT analisis.

b. Saran

1. Sekolah tinggi dalam tahap awal harus memastikan rasio dosen dengan mahasiswa harus terpenuhi melalui perekrutan baru

2. Meningkatkan kualitas staf pengajar melalui mengikuti kursus-kursus yang ada, seminar mendorong untuk menjadi pemakalah diseminar atau konferensi tertentu, memberikan dukungan untuk studi lanjut ke jenjang yang lebih tinggi

3. Sekolah tinggi mengoptimalkan jaringan kerjasama yang selama ini sudah ada, sehingga bisa menjadi sarana benchmark dalam peningkatan kualitas ekolah tinggi

4. Mulai secara serius untuk mempertimbangkan pembukaan progam studi baru atau minimal pembukaan konsentrasi-konsentrasi jurusan di stiap progam studi yang ada. 


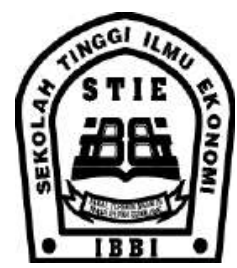

ISSN 1858-3199

JURNAL

MANAJEMEN BISNIS

STIE IBBI

5. Merencanakan membangun perpustakaan yang lebih professional melalui penamabhan buku-buku yang terbaru dan relevan serta kemungkinan memasuki era e-library. Dengan demikian suplai pengetahuan kepada civitas akademika semakin luas.

\section{DAFTAR PUSTAKA}

David, Fred. 2009. Manajemen Strategis, Buku 1. Jilid 19Salemba Empat. jakarta

Hamel, G \& Prahald C.K. 1998. Kompetisi Masa Depan. Harvard Business School Press

Porter, Michael E. 1994. Keunggulan Bersaing. Binarupa Aksara

Suwarno. 1996. Manajemen Strategik. YKPN, Yogyakarta

Gibson, Rowan. Rethinking the Future. 1998. PT. Gramedia Pustaka Utama, Jakarta

Rangkuti, F. 1999. Analisis SWOT Teknik Membedah Kasus Bisnis. PT. Gramedia Pustaka Utama. Jakarta

Pearc, J.A dan R.B. Robinson. 1997. Startegic Managemennt: Formulation, Implementation, amd Controll. Sixth Edition. USA: Richard D. Irwin

Jauch L. R.dan W.F.Glueck. 1994. Manajemen Strategi dan Kebijakan Perusahaan. Penerbit: Air Langga

Nuhung, H.I. 2000. “ startegi PengembanganAgribisnis berorientasi Ekspor Yang Berkelanjutan:. Semknar nasional INAGRI, Istora Senayan, Jakarta

Faulkner, D. dan Johnson, G 1995. Startegi Manajemen. Seri Stratgei Manjamen. Penerbit: Elex Media Komputindo, Jakarta.

Solahuddin, S. 1999. Diskusi Panel: “ Penggalangan Agribisnis sebagai leading sector menghadapi Era AFTA dan APEC: Tinjauan Strategik Kebijakan:. 22 Februari 1999, Hotel Horison, Jakarta

Render, B \& Heizer, J. 1997. Principles of Operation Management2nd. Prentice Hall. Inc. New Jersey 